Journal of East Asian Cultures 2021/1: 293-303

DOI: 10.38144/TKT.2021.1.18

https://orcid.org/0000-0001-6941-0823

uyanga@imu.edu.cn

WUYINGGA (UYANGA)

\title{
Introduction to the Mongolian Kinship Terminology in Inner Mongolia On the Example of Qarčin-Tümed Dialect
}

\section{Introduction to the Mongolian Kinship System}

Kinship is one of the main organizing principles of a society, ${ }^{1}$ and is one of the most basic social institutions, one which establishes relationships between individuals and groups. People in all societies are bound together by various bonds. The most basic bonds are those based on marriage and reproduction. Kinship refers to these bonds, as well as all relationships resulting from them. Thus, the institution of kinship refers to a set of relationships and relatives formed thereof, based on either the consanguineal or affinal. ${ }^{2}$ Consanguineal kinship refers to the relationships based on blood, for example, relationships between parents and children and those between siblings, which are the most basic and universal kinship. Affinal kinship refers to the relationships formed on the basis of marriage.

Detailed research on the Mongolian kinship system in western countries started with the epochal works of B. Ya. Vladimirtsov. According to him, the Mongolian kin: oboy was "the typical union of relatives by blood, based on the principle of agnate and exogamy, the patriarchal unit, with a few features of the former cognate relationships, the union tied by the institute of revenge and a special cult." ${ }^{3}$ Later on, L. Karder investigated the topic through anthropological studies in his work Social Organization of the Mongol-Turkic Pastoral Nomads. ${ }^{4}$

Research on Mongolian kinship terms started in the late $20^{\text {th }}$ century in China. The research during this period includes amongst others jaran-nige's Mongolian

\footnotetext{
${ }^{1}$ Farber 1981: 250.

2 Dousset: 2011.

${ }^{3}$ Владимирцов Б.Я. 2002: 354.

${ }^{4}$ Karder 1963.
} 
Kinship Terms written in 1981, ${ }^{5}$ Temürbayan's Mongolian Kinship Terminology (1984), ${ }^{6}$ Namsirai's Research on Mongolian Kinship terms (1987). However, only the terms of Mongolian kinship are briefly described and introduced in these articles.

Since the 1990s, there has been more research on Mongolian kinship terms, which has expanded on these descriptions of Mongolian kinship terms and their standardization. It has extended the discussion to the etymology of kinship terms, such as in Qasbayatur's (1994) "The Origin of Mongolian kinship terms 'Son-in-law', 'Daughter-in-law', 'Sister-in-law"'" and "The Origin of Mongolian kinship terms 'Mother', 'Sister', 'Wife' and 'Daughter."'9 The relationship between kinship terms and national culture, and the regional differences of kinship terms was researched by Fan Lijun A Study of Features of Kinship Terminology in Mongolian Dialect in Inner Mongolia, written in 2004. Wenying explored Mongolian cultural relics by the analysis of contemporary Mongolian kinship terms. ${ }^{10}$ Furthermore, there is research that mainly discusses the Mongolian marriage system, such as Tana's work, "Research on the Mongolian Marriage Form in The Secret History of the Mongols", ${ }_{11}^{11}$ which retrieves and researches the kinship terms of Middle Mongolian. Qasungerel analyzed the contemporary Mongolian kinship terminology from the perspective of semantics in 2011.

Compared to the kinship terminology of some other languages, as for example Hungarian or English (vernacular terms in today use), ${ }^{12}$ contemporary Mongolian kinship terminology is more complex and detailed. The Mongolian terminology has a corresponding term for almost every family member, differentiating between the maternal and paternal family relationships. For example, the grandfather on the maternal side has a different name from the grandfather on the paternal side; Ebüge means grandfather on the paternal side in the contemporary Mongolian, and naүaču ebüge means grandfather on the maternal side in the contemporary Mongolian. This contrasts with Hungarian or English (vernacular terms in today use) where the same term is used for both, e. g. nagyapa refers to both the maternal and paternal grandfather in Hungarian (vernacular terms in today use) as does grandfather in English (vernacular terms in use today). Like any other society, the Mongolian kinship system is classified

\footnotetext{
5 J̌aran-nige 1981.

${ }^{6}$ Temürbayan 1984.

Namsirai 1987.

Qasbayatur 1994.

9 Qasbayatur 1995.

${ }^{10}$ Wenying 2003.

11 Tana 1992.

${ }^{12}$ Hidasi 2014: 43-48.
} 
as consanguineal and affinal. However, consanguineal kinship is further divided into collateral consanguinity and lineal consanguinity. Lineal consanguinity is the relation in a direct line - such as between parent, child, and grandparent. Furthermore, it is also determined either upwardly - as in the case of son, father, grandfather - or downwardly - as in son, grandson, great-grandson. Collateral consanguinity is a more remote relationship describing people who are related by a common ancestor but do not descend from each other - such as cousins who have the same grandparents.

\section{Comparison of the Kinship Terminology of Middle Mongolian and Contemporary Mongolian}

By the $13^{\text {th }}$ century, Mongolian kinship terminology had already formed. The Secret History of The Mongols, the earliest and most important literary monument of the Mongol-speaking people, is the native account of the life and deeds of Chinggis Khan and his successors. Linguistically, it is the richest source of pre-classical Mongolian and Middle Mongolian. ${ }^{13}$

Indeed, The Secret History of The Mongols is regarded internationally a work of classic literature. It describes the formation, development, and growth of the Mongol empire, and the earliest existing historical literature of the Mongols. Both the marriage system and the kinship terminology have been recorded in this source. Jāmi al-tawārikkh is a work of literature and history, produced in the Mongol Ilkhanate in three volumes, written by Rashīd al-Dīn Faḍlullāh Hamadān $\overline{1}$ at the beginning of the $14^{\text {th }}$ century. It describes many cultures and major events in world history from China to Europe. Mongolian history, the life of the Mongols, wars, family and marriages were also recorded. The Jāmi 'al-tawārìkh consists of four main sections in which Ta'rīkh-ī Ghazāni is the most extensive part, and which includes the history, genealogies and legends of Mongolian and Turkish tribes. ${ }^{14}$

According to these records, the Mongolian marriage system was polygamous. ${ }^{15}$ Men could have multiple wives. For example, the father of Chinggis Khan had many wives from different tribes. ${ }^{16}$ Chinggis Khan himself and his brothers also

${ }^{13}$ As a spoken medium, the language of the historical Mongols is known as Middle Mongol, or Middle Mongolian. Middle Mongol is documented in a variety of written sources using several different systems of script (Janhunen 2012: 4). Written Mongol has ever since remained in use as the principal literary language of the Mongols. Evolving successively through stages termed PreClassical ( $13^{\text {th }}$ to $15^{\text {th }}$ centuries $)$, Classical ( $17^{\text {th }}$ to $19^{\text {th }}$ centuries $)$ and Post-Classical ( $20^{\text {th }}$ century).

${ }^{14}$ Cf. Aigle 2014.

15 Yu Dajun - Zhou Jianqi 1997: 6.

16 Yu Dajun - Zhou Jianqi 1997: 64. 
had more than one wife. ${ }^{17}$ Additionally, there was also the takeover-marriage: if the father died then his son could marry his wife, providing she was not his biological mother. ${ }^{18}$ If a man had brothers and one of the brothers died, then he could marry his wife as well. ${ }^{19}$ Due to these circumstances it was difficult to form a consistent kinship terminology.

Through historical developments, the marriage system has changed from being polygamous to being monogamous and has led to changes in kinship terminology over time. Regarding the study of the system of kinship in the Middle Mongolian period, Pavel Rykin's (2011) work is of the utmost importance.

Pavel examined thoroughly the use of kinship and affinity terms in Middle Mongolian, basing his research on all Middle Mongolian monumental works which were accessible to him, such as Beilu kao, Huayi Yiyu and so on, as the sources of linguistic material. Hence, the kinship and affinity terms appearing in the monumental works were selected and categorised according to their morphological structures: 'elementary' (independent words not dissolved into meaningful components), 'complex' (kinship or affinity terms modified by other kinship or affinity terms in the form of a stem), 'composite' (stems in combination with any determinative which it is not by itself a kinship or affinity term) and 'descriptive' (formed by the combination of several elementary or composite terms where the modifying element is expressed by the genitive) Simultaneously, he indicated the most extensive category is composed by the elementary terms, which is consistent with the following research conclusions.

In order to compare the historical changes of the Mongolian kinship terminology, twenty words for kinship terminology that are found in The Secret History of The Mongols and Huayi Yiyu, ${ }^{20}$ are compared with the contemporary Mongolian ( $20^{\text {th }}$ century) kinship terminology. I prepared tables $1,2,3$, and 4 on the basis of the sources mentioned above. In the table1, letters F, M, B, Z, S, $\mathrm{D}$ represent father, mother, brother, sister, son, and daughter. Symbols $(+)$ and $(-)$ represents elder and younger. The letter L represents Lineal consanguinity kinship. As shown in table 1, 2, 3, 4.

17 Yu Dajun - Zhou Jianqi 1997: 64, 67, 70, 71, 73, 85.

18 Yu Dajun - Zhou Jianqi 1997: 268-269.

19 Sárközi 2006.

${ }^{20}$ Huayi yiyu (1407) is a general term from the late Ming (1368-1644) and early Qing (16441911) period as a designation of multi-language dictionaries for officials confronted with one or more languages of the multi-ethnic empire and with foreign languages. 


\begin{tabular}{|l|l|l|l|}
\hline F father & Z sister & $(+)$ elder \\
\hline M mother & S son & $(-)$ younger \\
\hline B brother & D daughter & L Lineal consanguinity \\
\hline
\end{tabular}

Table 1. Explanation of abbreviations

\begin{tabular}{|c|c|c|}
\hline \multicolumn{3}{|c|}{ Consanguineal Kinship } \\
\hline English Kinship Terminology & Contemporary Mongolian Kinship Terminology & Middle Mongolian Kinship Terminology \\
\hline Great great grandfather $(\mathrm{FL})$ & 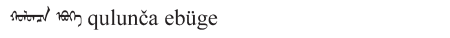 & किस्या' borqai \\
\hline Great great grandmother (FL) & Stvirest thing qulunča emege & - \\
\hline Great grandfather $(\mathrm{FL})$ & H̄ont & मिंग्न/ elünče \\
\hline Great grandmother $(\mathrm{FL})$ & Hiver & - \\
\hline Grandfather (FL) & trin ebüge & भrh ebüge \\
\hline Grandmother (FL) & thin emege & thin emege \\
\hline Father $(\mathrm{L})$ & $\operatorname{minh} /$ na ečige/ abu & भriß ečige \\
\hline Uncle $(F)(+)$ & 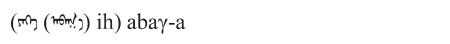 & tor/ ebin \\
\hline Uncle (F) (-) & abay-a & nom? abay-a \\
\hline Aunt $(\mathrm{F})(+)$ & $(m)$ & - \\
\hline Aunt (F) (-) & $n+m !)$ br abay-a eji & - \\
\hline Grandfather (ML) & mant nayač ebüge & - \\
\hline Grandmother (ML) & 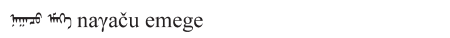 & - \\
\hline Mother (L) & breji & nh eke \\
\hline Uncle (M) $(+,-)$ & 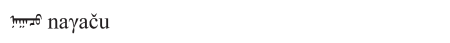 & 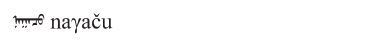 \\
\hline Aunt $(\mathrm{M})(+,-)$ & 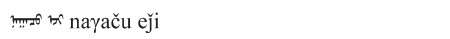 & - \\
\hline
\end{tabular}

Table 2. Comparison of Consanguineal Kinship Terminology

Mongolian kinship terminology has changed considerably not only in number but also concerning the word structure over time. It can be seen from the tables that all of the kinship terms in the Middle Mongolian consist of one single word, and some of these words are still maintained in contemporary Mongolian, while some have changed their meanings or are used for the opposite gender and some are no longer used. For instance:

1. Terms existing both in Middle Mongolian and contemporary Mongolian with the same meanings are elünče 'great grandfather', ebüge 'grandfather',

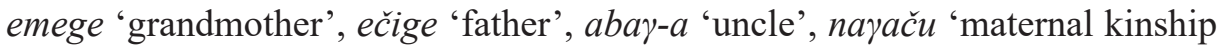
term', aq-a 'elder brother', degüü 'younger brother', egeči 'elder sister', ökin 'daughter', and jige 'nephew'. 


\begin{tabular}{|c|c|c|}
\hline \multicolumn{3}{|c|}{ Consanguineal Kinship } \\
\hline English Kinship Terminology & Contemporary Mongolian Kinship Terminology & Middle Mongolian Kinship Terminology \\
\hline Brother $(+)$ & $m^{\prime} / 3$ aq-a & $m / 3$ aq-a \\
\hline Brother (-) & mes degüü & mos degüü \\
\hline Sister $(+)$ & Mar egeči & War egeči \\
\hline Sister (-) & vorth mros ökin degüü & कor düi \\
\hline Cousin (FBS) & 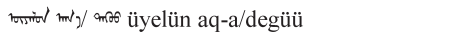 & - \\
\hline Cousin (FBD) & 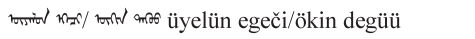 & - \\
\hline Cousin (FZS) $(\mathrm{M}(\mathrm{B} / \mathrm{Z}) \mathrm{S})$ & 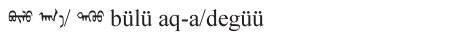 & - \\
\hline Cousin $(M(B / Z) D)$ & 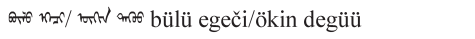 & - \\
\hline Son $(\mathrm{L})$ & nổ kü & 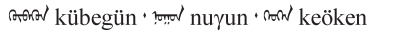 \\
\hline Daughter (L) & romt ökin & trint ökin \\
\hline Nephew (BS) & Hrs tôf ači küü & - \\
\hline Niece (BD) & nas toritr ači ökin & - \\
\hline Nephew (ZS) & min की jige küü & $\pi n$ ǰige \\
\hline Niece (ZD) & minh tornt jige ökin & - \\
\hline Grandson (SSL) & कि ombol küü & Hrs ači \\
\hline Granddaughter (SDL) & मिक्षि ombol ökin & - \\
\hline Grandson (DSL) & तु भîि की jige ombol küü & - \\
\hline Granddaughter (DDL) & 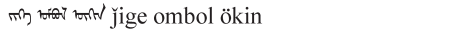 & - \\
\hline
\end{tabular}

Table 3. Comparison of Consanguineal Kinship Terminology

2. Terms existing in Middle Mongolian, but replaced in contemporary Mongolian are, for example, the word köken used to refer to son in the Middle Mongolian, but in contemporary Mongolian the term is used to refer to a girl or a daughter. The word düi once used to refer to a younger sister is today replaced by ökin degü̈̈. Ači used to refer to grandchildren but today refers to children of brothers and the term referring to the son changed from köbegün and nuүun to the küü.

3. Terms that exist in both Middle Mongolian and contemporary Mongolian but have different meanings. For example, there were different terms to differentiate elder uncle and younger uncle in Middle Mongolian, but term ebin which refers to elder uncle has not been passed down, only $a b a \gamma-a$ remains in contemporary Mongolian, which refers to both elder and younger uncle now. 


\begin{tabular}{|c|c|c|}
\hline \multicolumn{3}{|c|}{ Affinal Kinship } \\
\hline English Kinship Terminology & Contemporary Mongolian Kinship Terminology & Middle Mongolian Kinship Terminology \\
\hline Wife of uncle (F) & nom?, & - \\
\hline Husband of aunt (F) & की & - \\
\hline Wife of uncle (M) & Intrat & - \\
\hline Husband of aunt (M) & 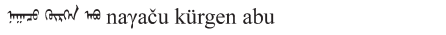 & - \\
\hline Wife of brother $(+)$ & tarnt bergen & - \\
\hline Wife of brother (-) & $m e \theta$ ors degüü beri & - \\
\hline Husband of sister $(+)$ & कित्रत/ $m$ ' , kürgen aq-a & - \\
\hline Husband of sister (-) & mes कात्wn degüü kürgen & - \\
\hline Father-in-law & भिज्ञ qadam abu & - \\
\hline Mother-in-law & smerl br qadam eji & - \\
\hline Brother $(+)$ in law & 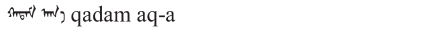 & - \\
\hline Brother (-) in law & 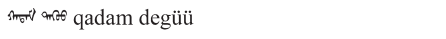 & - \\
\hline Sister $(+)$ in law & Amerl kñ qadam egeči & - \\
\hline Sister $(-)$ in law & Smert tornt ames qadam ökin degüü & - \\
\hline Son-in-law & कित्रत्w kürgen & - \\
\hline Daughter-in-law & ari beri & - \\
\hline
\end{tabular}

Table 4. Comparison of Affinal Kinship Terminology

\section{Kinship Terminology in a Contemporary Mongolian Dialect - Qarčin- Tümed Case Study}

The Inner Mongolian dialect ${ }^{21}$ is composed of multiple sub-dialects and there are great phonetic differences between these dialects. ${ }^{22}$ Some are mixed with Chinese loanwords due to their geographical location and historical background. This article focuses on the Qarčin-Tümed dialect as an example to reveal the differences of kinship terminology in Mongolian dialects.

The Qarčin-Tümed dialect belongs to the eastern dialects of Inner Mongolia. ${ }^{23}$ The eastern dialects include Qorčin and Qarčin-Tümed dialects. ${ }^{24}$ The characteristic feature of the Qarčin-Tümed dialect is the vowel *u of the initial syllable, which has become in certain positions a diphthong $u a$ or $\omega a$, and the

${ }^{21}$ Mongolian in China can be divided into three dialects: Inner Mongolian dialect, Baryu Buryat dialect, Oirat dialect. Cf. Činggeltei. 1991: 1

${ }^{22}$ Poppe 1965: 23.

23 Тодаева В. Х. 1985.

${ }^{24}$ Sečinbayatur 2005: 354 


\begin{tabular}{|c|c|c|c|c|c|c|c|c|c|}
\hline Paternal side & $\mathrm{FF}$ & FM & $\mathrm{F}$ & $\mathrm{FB}+$ & $\mathrm{F}(\mathrm{B}+) \mathrm{W}$ & FB- & FB (-) W & $\mathrm{FZ}(+)(-)$ & $\mathrm{FZ}(+)(-) \mathrm{H}$ \\
\hline $\begin{array}{l}\text { Standard } \\
\text { (Colloquialism) }\end{array}$ & öbög & emeg & ečig/aab & aba $\gamma$ & $\begin{array}{l}\text { aba } \gamma \\
\text { bergen ek }\end{array}$ & abay & $\begin{array}{l}\text { aba } \gamma \\
\text { bergen ek }\end{array}$ & abay eji & 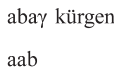 \\
\hline Dialect & yeye & nænæ & abaa & daya & damöm & šü šü & sinse & gügü & guya aab \\
\hline Chi. pinyin & ye ye & nai nai & ba ba & da ye & da ma & shu shu & shen zi & gu gu & gu fu \\
\hline Chi. hanzi & 爷爷 & 奶奶 & 爸爸 & 大爷 & 大妈 & 叔叔 & 婶子 & 姑姑 & 姑父 \\
\hline Maternal side & MF & MM & M & $\begin{array}{l}\text { MB (+) } \\
(-)\end{array}$ & $\begin{array}{l}\mathrm{MB}(+)(-) \\
\mathrm{W}\end{array}$ & $\mathrm{MZ}+$ & $\mathrm{MZ}(+) \mathrm{H}$ & MZ (-) & MZ (-) H \\
\hline $\begin{array}{l}\text { Standard } \\
\text { (Colloquialism) }\end{array}$ & nayač öbög & $\begin{array}{l}\text { nayač } \\
\text { emeg }\end{array}$ & ek & nayač & $\begin{array}{l}\text { nayač } \\
\text { bergen ek }\end{array}$ & $\begin{array}{l}\text { naүač } \\
\text { eji }\end{array}$ & $\begin{array}{l}\text { nayač } \\
\text { kürgen } \\
\text { aab }\end{array}$ & nayač eji & $\begin{array}{l}\text { nayač } \\
\text { kürgen aab }\end{array}$ \\
\hline Dialect & naya yeye & $\begin{array}{l}\text { naүa } \\
\text { nænæ }\end{array}$ & mömö & jüüjü & jümü & $\begin{array}{l}\text { naya } \\
\text { eeyi }\end{array}$ & naya aab & naүa ǰĕ & naya aab \\
\hline Chi. pinyin & wai gong & wai po & ma ma & jiu jiu & jiu ma & yi ma & yi fu & xiao yi & xiao yi fu \\
\hline Chi. hanzi & 外公 & 外婆 & 妈妈 & 舅舅 & 舅妈 & 姨妈 & 姨夫 & 小姨 & 小姨夫 \\
\hline Ego & $\mathrm{B}+$ & $\begin{array}{ll}\mathrm{B} & (+) \\
\mathrm{W} & \end{array}$ & B- & B (-) W & $\mathrm{Z}^{+}$ & $\mathrm{Z}(+) \mathrm{H}$ & Z- & $\mathrm{Z}(-) \mathrm{H}$ & - \\
\hline $\begin{array}{l}\text { Standard } \\
\text { (Colloquialism) }\end{array}$ & ah & bergen & düü & düü ber & egeč & $\begin{array}{l}\text { kürgen } \\
\text { ah }\end{array}$ & ökin düü & $\begin{array}{l}\text { düü } \\
\text { kürgen }\end{array}$ & - \\
\hline Dialect & göög/aǰa/aǰe & bergen & $\begin{array}{l}\text { anggaa/ } \\
\text { düü }\end{array}$ & düü ber & јеје & $\begin{array}{l}\text { kürgen } \\
\text { ah }\end{array}$ & $\begin{array}{l}\text { ikin } \\
\text { düü }\end{array}$ & $\begin{array}{l}\text { düü } \\
\text { kürgen }\end{array}$ & - \\
\hline Chi. pinyin & ge ge & sao zi & di di & di xi & jie jie & jie fu & mei mei & mei fu & - \\
\hline Chi. hanzi & 哥哥 & 嫂子 & 弟弟 & 弟媳 & 姐姐 & 姐夫 & 妹妹 & 妹夫 & - \\
\hline Affinal kin & $\mathrm{S}$ & SW & $\mathrm{D}$ & $\mathrm{DH}$ & SS & $\mathrm{SD}$ & DS & DD & - \\
\hline $\begin{array}{l}\text { Standard } \\
\text { (Colloquialism) }\end{array}$ & küü & küü ber & ökin & $\begin{array}{l}\text { ökin } \\
\text { kürgen }\end{array}$ & ombol küü & $\begin{array}{l}\text { ombol } \\
\text { ökin }\end{array}$ & $\begin{array}{l}\text { ǰee ombol } \\
\text { küü }\end{array}$ & $\begin{array}{l}\text { jee ombol } \\
\text { ökin }\end{array}$ & - \\
\hline Dialect & küü & ber & ikin & kürgen & ombol küü & $\begin{array}{l}\text { ombol } \\
\text { ikin }\end{array}$ & $\begin{array}{l}\text { ǰee ombol } \\
\text { küü }\end{array}$ & $\begin{array}{l}\text { ǰee ombol } \\
\text { ikin }\end{array}$ & - \\
\hline Chi. pinyin & er zi & er xi & nv er & $\mathrm{nv} x u$ & $\operatorname{sun} z i$ & sun nv & wai sun & $\begin{array}{ll}\text { wai sun } \\
\text { nv }\end{array}$ & - \\
\hline Chi. hanzi & 儿子 & 儿媳 & 女儿 & 女婿 & 孙子 & 孙女 & 外孙 & 外孙女 & - \\
\hline
\end{tabular}

Table 5. Comparison of Contemporary Written Mongolian and Küriy-e Sub-dialect (Wuyingga 2020)

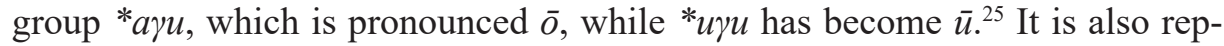
resentative of a dialect most affected by Chinese. In the early studies, some scholars divided the Qarčin-Tümed dialect into Qarčin sub-dialect and Tümed sub-dialect. Later, some scholars divided it into Qarčin sub-dialect, Mongroljin 
sub-dialect and Küriy-e sub-dialect. ${ }^{26}$ In order to show the differences between kinship terminology in Mongolian dialect and contemporary written Mongolian, the following comparison was made. Küriy-e sub-dialect is selected for comparison. As shown in Table 5.

As mentioned above, letter $\mathrm{F}$ refers to father, here FF refers to the father of father, FM refers to the mother of father (which are the paternal grandparents), $\mathrm{H}$ refers to Husband, W refers to wife, SW means wife of son, DH means husband of daughter. Due to the geographical location and historical background, the Mongolians living in this area have always had linguistic and cultural contact with the Han populations and Manchus. As such,the appearance of Chinese loanwords in their dialects is an inevitable result.

As we can see from the table, some Chinese loanwords appeared in the kinship terminology of Küriy-e sub-dialect; these terms were borrowed and used in their dialect after Mongolization, such terms as yeye (vernacular terms) 爷爷 'grandfather on paternal side', nainai (vernacular terms) 奶奶 'grandmother on paternal side', daya (vernacular terms) 大爷 'elder brother of father', gügü (vernacular terms) 姑姑 'elder sister of father', göög (vernacular terms) 哥哥 'elder brother' and so on. Some kinship terminologies are the combinations of Chinese and Mongolian words, such as damöm (vernacular terms) 'wife of elder uncle', ruya abu (vernacular terms) 'husband of aunt', nay-a nainai (vernacular terms) 'grandmother on maternal side', nay-a yeye (vernacular terms) 'grandfather on maternal side' and so on. The Chinese word $D a$ 大 means big and elder; the $d a$ being borrowed from the Chinese and Mongolian word mömö (vernacular terms) 'mother' has been added to refer to wife of elder uncle. Similarly, guye 姑爷 borrowed from Chinese and pronounced as ruya and then Mongolian word $a b u$ 'father' has been added to refer to husband of aunt. It is the same with $n a \gamma-a$ nainai and nay-a yeye.

The combination of Chinese loanwords and Mongolian words as kinship terminology distinguishes the Küriy-e subdialect from other dialects. This phenomenon not only appears in the kinship terms, but also in their daily life. Through field investigations I have found that, since people speaking in Küriy-e sub-dialect have in the majority of cases been neighbours with the Han populations, they have been in contact with Han cultures earlier, and the impact of Han cultures has often led to the phenomenon of mixed language in daily conversations. They borrowed Chinese words and used them after mongolization. ${ }^{27}$

26 Sodubayatur 1999: 99

27 E. g. dianhua da-y-a (dian hua 电话 is telephone in Chinese, $d a$ 打 means call in Chinese, $y-a$ is a Mongolian suffix refers to future time) means "I will call you". 


\section{Conclusion}

Language is not only a communication tool, but also a carrier of culture. Local characteristics in culture are largely reflected and inherited by language. Kinship terminology is a language carrier that reflects human relation and is a primitive vocabulary of humans and belongs to basic terminology. By comparing the terminology of Mongolian kinship of the Middle Mongolian with contemporary Mongolian, most of the terms are still used now and they are all composed of one single word. With the development of society, intercultural interactions are becoming more and more influential, therefore, some terms with a compound-word structure appeared. Mongols living in Eastern Inner Mongolia are neighbours with the Han populations since the establishment of the Qing dynasty (1636-1912) and the fact that some Chinese loanwords appear in their dialects is inevitable.

\section{References}

Aigle, Denise 2014. The Mongol Empire between Myth and Reality. Studies in Anthropological History. Boston: Brill Academic Publication. https://doi.org/10.1163/9789004280649

Владимирцов Б.Я. 2002. Работы по истории и этнографии монгольских народов. [Works on History and Ethnography of the Mongols]. Москва: Восточная литература РАН.

Činggeltei 清格尔泰 1991. Meng Gu Yu Yu Fa 蒙古语语法 [Mongolian Grammar]. Hohhot: Nei Meng Gu Ren Min Chu Ban She 内蒙古人民出版社.

Dousset, Laurent 2011: "Understanding Human Relations (Kinship Systems).” In: N. Thieberger (ed.). The Oxford Handbook of Linguistic Fieldwork. Oxford: Oxford University Press, 209234. https://doi.org/10.1093/oxfordhb/9780199571888.013.0010

Fan lijun 范丽君 2004. Nei Meng Gu Fang Yan Qin Shu Cheng Wei Ci Wen Hua Te Zheng Yan $J i u$ 内蒙古方言亲属称谓词文化特征研究 [A Study of Features of Kinship Terminology in Mongolian Dialect in Inner Mongolia]. (MA dissertation, Inner Mongolia University).

Fan lijun 范丽君 2005. “Meng Gu Yu Nei Meng Gu Fang Yan Qin Shu Cheng Wei Ci Zhong Han Yu Jie Ci Te Dian 蒙古语内蒙古方言亲属称谓词中汉语借词特点 [Characteristics of Chinese Loanwords in the Terminology of Kinship in Inner Mongolian Dialect]." Zhong Yang Min Zu Da Xue Xue Bao 中央民族大学学报 6.32: 139-142.

Farber, Bernard 1981. Concepts of Kinship. New York: Elsevier.

Hidasi, Judit 2014. "Kinship Terminology from a Cultural Perspective: Japanese versus? Hungarian." The Society for Gender Studies in Japanese 14: 43-48.

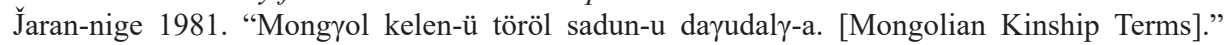
Mongyol kele bičig 3: 2-8.

Karder, Lawrence 1963. Social Organization of the Mongol-Turkic Pastoral Nomads [Indiana University Uralic and Altaic Series 20]. The Hague: Mouton.

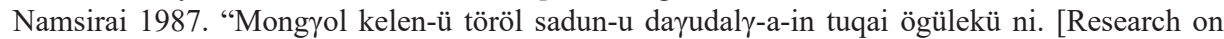
Mongolian Kinship Terms]." Mongyol kele bičig 9: 24-34. 
Pavel, Rykin 2011. "The System of Kinship and Affinity Terms in Middle Mongolian". Acta Orientalia Academiae Scientiarum Hungaricae 64.1: 25-47. https://doi.org/10.1556/AOrient.64.2011.1.3

Poppe, Nicholas 1965. Introduction to Mongolian Comparative Studies. Wiesbaden: Otto Harrassowitz.

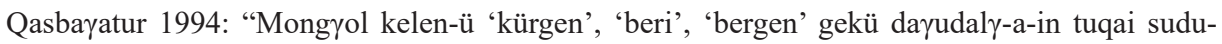
laqu ni [Research on the Mongolian Kinship Terms of Son-in-law, Daughter-in-law, Sister-in-

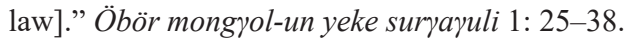

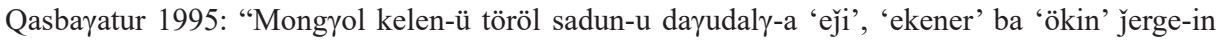
egusgel $\gamma$ arul-in sudulul [On the etymology of the terms mother, wife and daughter in Mon-

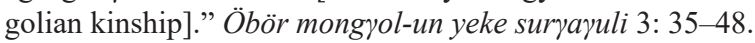

Qasungerel 哈申格日乐 2011. Xian Dai Meng Gu Yu Chang Yong Qin Shu Cheng Wei Ci De Yu Yi Fen Xi 现代蒙古语常用亲属称谓词的语义分析 [A Semantic Analysis of Kinship Terminology in Contemporary Mongolian]. (PhD dissertation, Zhong Yang Min Zu Da Xue中央 民族大学).

Qin Xinlin 秦新林 1998.“Yuan dai meng gu zu de hun yin xi su ji qi bian hua 元代蒙古族的婚 姻习俗及其变化 [Changes of Mongolian Marriage Customs in Yuan Dynasty]." Yin Du Xue Kan 殷都学刊 1998.4: 33-36.

Rachewiltz, Igor de 2015. The Secret History of the Mongols: A Mongolian Epic Chronicle of the Thirteenth Centruy. Canberra, AU: Brill

Sárközi, Alice 2006. "Levirate among the Mongols." In: Kinship in the Altaic World (Asiatische Forschungen Bd. 150). Wiesbaden: Harrassowitz, 259-267.

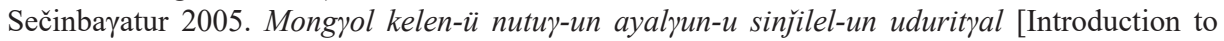
Mongolian Dialects]. Kökeqota: Öbör mongyol-un arat-un keblel-ün qoriy-a.

Sodubaratur 曹道巴特尔 1999. "Nei Meng Gu Fang Yan Tu Yu Hua Fen He Ka La Qin Tu Mo Te Yu Yan Jiu 蒙古语方言土语划分和喀喇沁土默特语研究 [The Division of Mongolian Dialect and the Study of Qarčin-Tümed].”Man Yu Yan Jiu 满语研究 2: 98-107.

Tana 1992. "Shi lun 'meng gu mi shi' zhongde gu dai meng gu zu hun yin xing tai 试论“蒙古 秘史”中的古代蒙古族婚姻形态 [On the Ancient Mongolian Marriage Forms in The Secret History of Mongols].” Hei Long Jiang Min Zu Cong Kan 黑龙江民族从刊 3: 34-50.

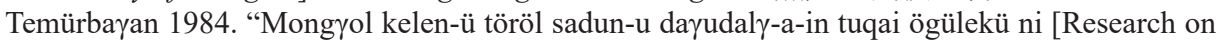
Mongolian Kinship Terms]." Mongyol kele bičig 3: 12-20.

Тодаева В. Х. 1985. Язык Монголов Внутренней Монголии: Очерк Диалектов. [The Language of the Mongols of Inner Mongolia: Outline of Dialects]. Москва: Наука.

Wenying 2003: "Shi Lun Min Zu Qin Chu Cheng Wei Suo Fan Ying De Min Zu Wen Hua Xian Xiang 论蒙古民族亲属称谓所反映的民族文化现象 [On the Ethnic Cultural Phenomenon Reflected in the Terms of Mongolian Kinship].” Xi Bei Min Zu Xue Yuan 西北民族学院 1: 30-37.

Yu Dajun 余大均 - Zhou Jianqi 周建奇 1997. Shi Ji 史集 [World History]. Beijing: Shang Wu Yin Shu Guan.

Zhang Zhiming 张志明 2007. Meng Yuan She Hui Hun Yin Zhi Du Liu Bian Qian Xi 蒙元社会 婚姻制度流变浅析 [An Analysis of Mongolian Marriage System in Yuan Dynasty]. (MA dissertation, Xi Nan Zheng Fa Da Xue 西南政法大学).

\section{Fieldwork}

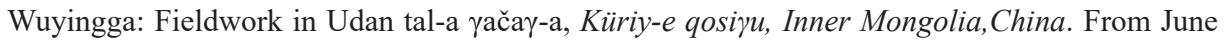
to July 2019. 
